\begin{tabular}{|l|l|l||}
\hline \multicolumn{2}{|c|}{ PublisherInfo } \\
\hline \hline PublisherName & $:$ & BioMed Central \\
\hline \hline PublisherLocation & $:$ & London \\
\hline \hline PublisherImprintName & $:$ & BioMed Central \\
\hline \hline
\end{tabular}

\title{
IL-1ra deficiency and atherosclerosis
}

\begin{tabular}{||l|l|l||}
\hline \multicolumn{2}{|c||}{ ArticleInfo } \\
\hline \hline ArticleID & $:$ & 184 \\
\hline \hline ArticleDOI & $:$ & $10.1186 /$ ar-2000-66809 \\
\hline \hline ArticleCitationID & $:$ & 66809 \\
\hline \hline ArticleSequenceNumber & $:$ & 141 \\
\hline \hline ArticleCategory & $:$ & Paper Report \\
\hline ArticleFirstPage & $:$ & 1 \\
\hline \hline ArticleLastPage & $:$ & 3 \\
\hline \hline & $:$ & RegistrationDate : 2000-5-9 \\
ArticleHistory & $:$ & OnlineDate \\
\hline \hline ArticleCopyright & $:$ & Current Science Ltd2000-5-9 \\
\hline \hline ArticleGrants & $:$ & \\
\hline \hline ArticleContext & $:$ & 130753311 \\
\hline \hline
\end{tabular}


Oliver Fitzgerald, Aff1

Aff1 St Vincent's University Hospital, Dublin

\section{Keywords}

Arterial inflammation, interleukin 1 receptor antagonist

\section{Context}

IL-1ra antagonises the action of IL-1 by binding to the type I IL-1 receptor. In this study, mice homozygous for a null mutation in the gene encoding IL-1 ra have been generated. In view of the possible role of IL-1 in the development of atherosclerosis, the arteries of these mutant animals were examined in some depth. To explore the role of IL-1 in the pathogenesis of atherosclerosis.

\section{Significant findings}

IL-1ra deficient mice crossed to the outbred strain MF1 were shown to develop severe arterial inflammation, in particular involving branch points of the aorta, and its primary and secondary branches. An excess in mortality $(>80 \%)$ due to organ infarction and ruptured aneurysms was seen compared to controls. Of 46 IL-1ra deficient mice, 43 had arterial inflammation and 16 had ruptured aneurysms or evidence of internal haemorrhage. By immunohistology, the atherosclerotic lesions were found to contain abundant neutrophils, macrophages expressing IL-1, and CD4 ${ }^{+}$Tcells. Arterial lesions could also be identified in mice heterozygote for the mutation. IL-1 ra deficient mice bred in pathogen-free conditions develop a lethal arteritis similar to that observed in mice bred conventionally.

\section{Comments}

The pathogenesis of atherosclerosis is not fully understood. Current concepts suggest that interleukin 1 (IL-1), produced by macrophages in atherosclerotic plaques, stimulates the local production of platelet-derived growth factor which in turn promotes smooth muscle cell and fibroblast proliferation. In this study, interleukin 1 receptor antagonist (IL-1 ra) -deficient animals are shown to develop premature and severe atherosclerosis. This indicates that the unopposed action of IL-1 is likely to be responsible 
for arterial wall damage. While the authors attempt to exclude a role for bacterial pathogens in their model, a role for resident pathogens has not been ruled out. In addition, this disease phenotype differs from another line of IL-1 ra deficient mice which do not develop arteritic lesions, but develop a chronic inflammatory arthropathy. Mouse strain differences implicate other genes in the expression of this mutation. Understanding the molecular basis for these differences in phenotype require further investigation.

\section{Methods}

Mouse colonies were established that were homozygous for the null mutation in the gene encoding IL-1ra. The carriage of the mutation was followed by polymerase chain reaction (PCR) analysis of DNA extracted from ear-clippings. Arteries from animals were examined both macroscopically and by immunohistology. To exclude a role for viral and bacterial pathogens, a separate colony of mice was bred under specific pathogen-free conditions.

\section{Additional information}

\section{References}

1. Nicklin MJH, Hughes DE, Barton JL, Ure JM, Duff GW: Arterial inflammation in mice lacking the interleukin 1 receptor antagonist gene. J Exp Med. 2000, 191: 303-311.

This PDF file was created after publication. 